\title{
RELATIONSHIP BETWEEN SCHOOL SELF-CONCEPT AND ACADEMIC PERFORMANCE
}

\author{
Dominika Hosova
}

doi: 10.18355/PG.2019.8.2.11

\begin{abstract}
In our article, we are focused on the exploration of the relation between the school self-concept and the academic performance. We assume that positive self-concept is in relation to better school performance. We tested the research hypothesis using data obtained on a sample of 420 pupils of the second grade. We used two research methods: The Self-Description Questionnaire and GPA (Grade Point Average). We can confirm the hypothesis. The results show that promoting pupil's self-concept of pupils improves pupils' performance at school.
\end{abstract}

\section{Key words}

self-concept, school self-concept, academic performance, pupils

\section{Introduction}

In present days, there is a strong tendency of increasing pressure for better performance not only in work but also in school. According to J. Kotasova (2001), the lack of positive incentives in the assessment of the environment is causing a weakening of ones' self-concept and is a threat to self-fulfillment. Reducing performance and distinguishing oneself from the standard could be considered by pupil as personal threat. Evaluation in the area of school performance significantly affects pupil's performance, motivation and their aspirations can trigger different motivational tendencies in relation to the results achieved. It is important to identify the cause of your own performance so that it does not interfere with the idea of yourself. Also, the overall atmosphere at school and the teachers' attitude to evaluation plays very important role. The teacher as well as pupils, should know what they have learned. And for that, feedback is needed to be fast, frequent and for all pupils. The acceptance or non-acceptance of a pupil's assessment also plays an important role whether it is a school grade, verbal assessment or praise. And these factors affect pupil's behavior and his further learning.

\section{School self-concept}

As stated in various studies (example L. Foglova, 2017; V. Konecna, 2010, J. Mudrak, 2015) the crucial factors for the formation of self-concept within the school environment are the personality of the teacher, class and school environment, school grades, teaching materials and others. In school age, the self-image is unstable and can change quite a lot. The positive judgment of teacher leads to positive growth and improve in the self-concept of pupils. Another very important factor that forms self-concept is the group of peers, its importance grows with age and dominates them during the puberty. 
Acceptance by peers is a prerequisite for inclusion in the adult world towards independence and maturity.

Self-concept in relation to school is called academic self-concept, which is one of the main components of general self-concept. The self-concept in the area of school performance significantly affects the pupil's performance motivation and their aspiration (I. Polednova, 2009).

Authors, P. Macek, L. Sulova and V. Konecna (In I. Polednova, 2009) report that school self-concept has a significant impact on school performance. Pupils evaluate and compare their performance. They compare performance with their classmates, but also with their own performance in different areas. Undoubtedly, therefore, expectation as well as teacher evaluation have a great influence on school self-concept. And these influences have been addressed in the last century by authors such as R. Rosenthal and L. Jacobson (1968) and also by D. W. Jamieson, J. E. Lydon, G. Steward and M. P. Zanna (1978)

The school self-concept still does not have a clear definition or structure up to this date, our article is based on understanding of school self-concept as presented by to W. C. Liu and C. K. J. Wang (2005). These authors take the understanding of school self-conception as a joy of working at school. Based on this parameter, H. W. Marsh (1992) measures school self-concept in his questionnaire.

From the point of view of the pupil's development, the attitude of the teacher, the classmates' attitude, and also the attitude he has towards himself has a great influence on his / her self-concept and experience. These attitudes determine who the pupil is, what he thinks, what he does and what he can become. It is this approach that has a strong power towards themselves. . J. Canfield and H. C. Wells (1995) state that in order to promote positive school self-concept, it is necessary to create an open school environment full of interest and should provide a sense of security, appreciation, trust, free expression without mocking, friendly environment, cooperation, discussion, but also talking about important topics such as fear, trust and others. The focus of education on the positive building of self-concept has an impact on pupils' healthy self-confidence, open relationship to other people to the environment and tasks. On the other hand, negative self-perception is manifested in pupils' lack of interest in learning, impaired benefits, undisciplined behavior, increased anxiety, lability, but also vulnerability.

The author R. Capek (2017) is also interested in self-conception of pupils in his publication. According to him, good grades and praise not only improve the atmosphere in the classroom and make them happy, but also greatly influence the pupil's self-concept. This also positively influences his motivation, perception of the subject, as well as his / her relationship with the teacher. R. Capek emphasizes that self-concept is perhaps the most important because the pupil's perception affects his or her classwork.

\section{School performance}


The issues of school performance, school success or failure are the issues of present time is schools. Therefore teachers, parents, pupils as well as public pays a lot of attention to this up-to-date topic. The understanding of school success and failure inherently affects the pupil's personality, self-esteem, emotions, overall awareness and behaviour. Success or failure generally expresses an individual's relationship to an activity as it applies. In this sense, school success is understood as a measure of pupil's work in school.

When the pupils' school performance or their behaviour corresponds to the requirements of the school, we can consider it as school success. Such requirements include school curriculum, school content and performance standards, learning roles given for the year and subjects. We are talking about failure when performance, respectively, the pupil's behaviour, does not meet these requirements or does not correspond to his / her abilities and abilities (J. Hvozdik, 1986).

The school assessments, specifically school grades, affect the pupil's selfesteem, self-esteem, dreams, desires and willpower. Each pupil experience the school evaluation in different ways. It depends on the nature, temperament and psychological characteristics of each individual. School assessment forms the school environment and also determines its motivation to learn.

The teacher's approach towards pupil's assessment should not be left out. Research by German authors U. Trautwein, O. Ludtkeo, O. Koller and J. Baumert (2006) in secondary school has shown that academic self-concept is linked to school performance and overall self-assessment depending on the assessment rules applied and the school atmosphere. The most common scenario is using school grade as an instrument for pursuit of the greatest objectivity in evaluation. The school grade is considered as the final product of pupil assessment. The grading always compares the pupil's performance with the set criteria - performance standards.

\section{Participants and Methods}

We tested the research hypothesis by the data required from sample of 420 pupils in the age between 11 and 16 years, respectively form the $7^{\text {th }}$ to the $9^{\text {th }}$ classes of the primary schools in Slovak republic. We used two research methods: The Self-Description Questionnaire, specifically short form - SDQII-S (L. A. Ellies, H. W. Marsh and G. Richards, 2002). Pupils have completed the questionnaire by self-rating items on a 6-point, Likert-type scale. This scale ranges from 1 (I do not agree) to 6 (I agree). The questionnaire is composed of 11 factors, for research purposes researched only one factor - school self-concept. Second methods were GPA (Grade Point Average). We put school self-concept in relation to the arithmetic average of pupil's grades (GPA).

\section{Results}

The school self-concept of the examined pupils $(\mathrm{R}=-0.5479)$ correlates statistically significantly with the results at school, namely the average of grades. That means that for pupils with an increase in school self-concept, the average of grades at school is improving. As an illustration, we can see a 
graphical representation of the correlation in Figure 1. BF_T represents school self-concept and $\mathrm{B}$ is the average of grades. We used the rank correlation coefficient to determine the degree of dependence between these features.

Since the scaling of SDQ-II-S is from 1 to 6 , where 6 is the best rating, however the scale of school grades has the opposite trend - value 5 is the worst grades, therefore all correlation coefficients are negative numbers. Formulated hypothesis can be supported. Results indicate that support of the school self-concept' pupils make improvements performance in school.

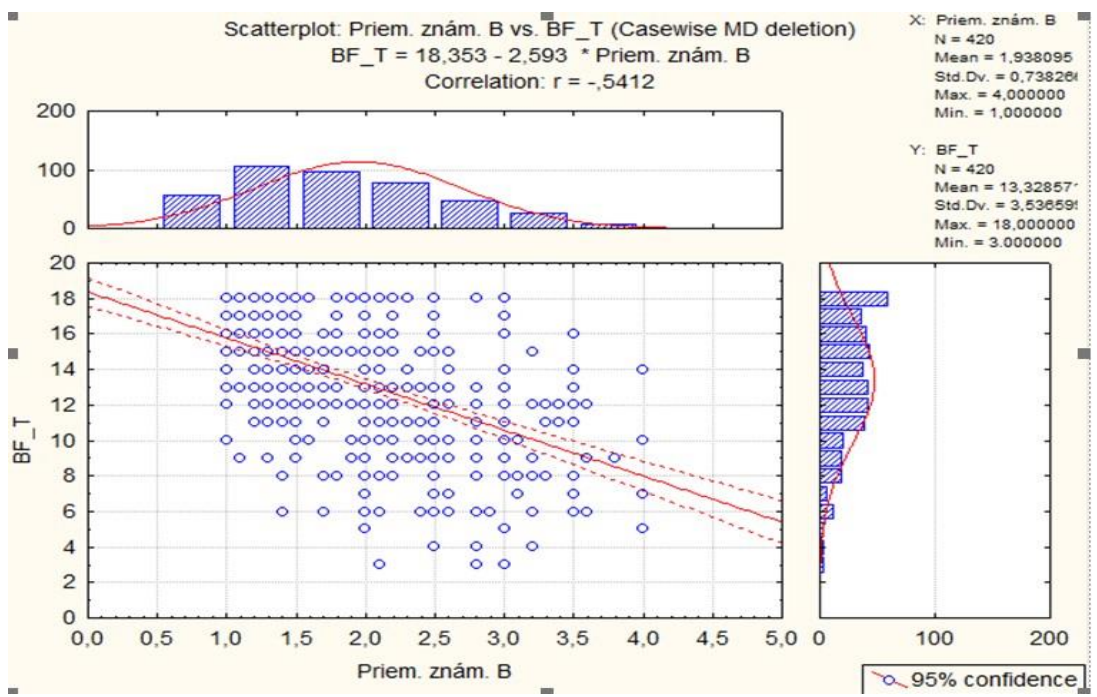

Picture 1: Correlation of school self-conception and GPA

\section{Discussion}

The grades are perceived differently by each pupil, they may motivate some pupils significantly, but some may also be demotivated to perform any additional performance. In our research, Spearman's rank correlation coefficient showed us that there is a significant degree of relation between school self-concept and school performance. Older research confirms our findings. Z. Matejcek and M. Vagnerova (1992) confirm the relationship between self-concept and school performance and state that self-concept of a pupil is a fundamental variable that affects his / her work motivation and persistence in work and tasks.

Later on, D. B. McCoachova and D. DelSiegle (2002) also examined the relationship between the academic self-concept and GPA. Their research showed a positive correlation between the two variables, as our research shows. However, school self-concept is dependent on systematic comparison. Pupils are constantly compared with their classmates and with prescribed standards. Such a comparison is also influenced by information from both teachers and parents. They often comment on the school performance of their 
children / pupils, which they consider good or bad, by expressing different attitudes. And these attitudes are automatically passed on to the children / pupils themselves and their perception of themselves. They identify with the opinions of authorities and begin to perceive and evaluate themselves according to what they hear from others. Therefore, parents and teachers should pay attention to their own statements about children / pupils, their characteristics, abilities and not to express any negative conclusions and prognosis

\section{Conclusion}

It is crucial to realize that school self-concept influences not only school performance but also the pupil's progress in life. The school self-concept is an essential component of the overall image that an individual creates about himself. It includes ideas about his / her own school abilities, as well as his / her perception of effort and interest in school life. Foreign researches, as well as our findings confirm a significant degree of linkage between school selfconcept and pupils' learning performance. That is why it is necessary to raise awareness of the issue of self-concept of pupils in schools, as it affects their performance. In foreign countries, the development and maintenance of positive self-concept is emphasized as one of the most important goals of education, while in our country knowledge in this area is not sufficiently available to our teachers. The area of self-conception school be included in the personal development of pupils in the educational process.

Self-concept issue in school practice needs be considered essential and it is important to work on every single component of self-concept. It affects the pupil's overall thinking about himself, his abilities, goals, social inclusion, and especially his motivation as well as results in his school performance.

\section{Acknowledgements}

This study has been written under the project: APVV-15-0368 Practice in the center of the subject field didactics, subject field didactics in the center of preparation for practice.

\section{Bibliographic references}

DUCHOVICOVA, J. 2005. Diferencované hodnotenie žiakov - významný didaktický problém. In Diferenciácia ako prostriedok zefektívnenia pedagogickej činnosti v školských zariadeniach. Nitra: Pedagogická fakulta UKF Nitra. ISBN 808050900X.

DUCHOVICOVA, J. 2018. Philosophical and research aspects of diversity. In XLinguae, Vol. 11 Issue 1XL, p. 43-57, ISSN 1337-8384. DOI: 10.18355/XL.2018.11.01XL.05

DUCHOVICOVA, J. - KOLENAKOVA, R. S. 2018. Mental mapping strategy in educative process and the quality of pupil's learning performance. In: XLinguae, Vol. 11, Issue 2, p. 528 - 540, ISSN 1337-8384, DOI: 10.18355/XL.2018.11.02.43.

ELLIS, L. A. - MARSH, H. W. - RICHARDS, G. 2002. A Brief Version of the Self Description Questionnaire II. Retrieved from 
https://www.researchgate.net/publication/266223536_A_Brief_Version_of_t he_Self_Description_Questionnaire_II.

FOGLOVA, L. 2017. Self - efficacy a subjektívna pohoda ako determinanty školskej úspešnosti žiakov. Dizertačná práca. PF, UKF Nitra.

JAMIESON, D. W. - LYDON, J. E. - STEWARD, G. - ZANNA, M. P. 1978. Pygmalion revisited: New evidence for student expectancy effects. In Journal of Educational Psychology, vol. 79, pp. 461-466.

KONECNA, V. 2010. Sebepojetí a sebehodnocení rozumově nadaných dětí. Brno: Tisk MSD, spol. s. r. o. ISBN 978802105325-0.

MACEK, P. - SULOVA L. - KONECNA, V. 2009. Proměny vztahu k sobě v průběhu dětství a dospívání. In Sebepojetí dětí a dospívajících v kontextu školy. Brno: Muni press. ISBN 978-80-210-5085-3.

MATEJCEK, Z. - VAGNEROVA, M. 1992. Dotazník sebepojetí školní úspěšností dětí - SPAS. Bratislava: Psychodiagnostika.

ROSENTHAL, R. - JACOBSON, L. 1968. Pygmalion in the Classroom. New York: Holt, Rinehart and Winston.

MUDRAK, J. 2015. Nadané děti a jejich rozvoj. Praha: Grada Publishing. ISBN 9788024750897.

KOTASOVA, J. 2001. Existenciálně analytické pojetí školní fobie. In Psychológia a patopsychológia diet’at’a, roč. 36, č. 2, s. $161-174$.

POLEDNOVA, I. 2009. Sebepojetí dětí a dospívajících v kontextu školy. Brno: Masarykova univerzita. ISBN 978-80-210-5085-3.

HVOZDIK, J. 1986. Základy školskej psychológie. Bratislava: SPN.

CAPEK, R. 2017. Líný učitel. Jak učit dobře a efektivně. Bratislava: Raabe. ISBN 9788074963445.

CANFIELD, J. - WELLS, H, C. 1995. Hry pro zlepšení motivace a sebepojetí žákú. Praha: Portál. ISBN 8071780286.

LIU, W. C. - WANG, C. K. J. 2005. Academic self-concept: A crosssectional study of grade and gender differences in a Singapore Secondary School. In Asia Pacific Education Review, vol. 6, no. 1, pp. 20-27.

MARSH, H.W. 1992. Self Description Questionnaire (SDQ) I: A theoretical and empirical basis for the measurement of multiple dimensions of preadolescent self-concept. A test manual and research monograph. San Antonio: The Psychological Corporation.

MCCOACH, B. D. - DelSIEGLE, D. 2002. The structure and function of academic self-concept in gifted and general education students. In Roeper Review, vol. 25, no. 2, pp. 61-65.

PUSHKAREV, Y.V. - PUSHKAREVA, E. A. 2018. Philosophical interpretation of knowledge and information: knowledge value and information diversity in modern communication. In XLinguae, Volume 11, Issue 3, p. 176-184, ISSN 1337-8384, DOI: 10.18355/XL.2018.11.03.17

TRAUTWEIN, U., et al. 2006. Self-esteem, academic self-concept, and achievement: How the learning environment moderates the dynamics of selfconcept. In Journal of Personality and Social Psychology, vol. 90, no. 2, pp. 334-349.

TYURIKOV, A.G. 2018. New social reality in the context of information and communication technologies. In: XLinguae, Volume 11, Issue 3, pp. 37-75, ISSN 1337-8384, DOI: 10.18355/XL.2018.11.03.06 
Mgr. Dominika Hošová

Department of pedagogy

Faculty of education

Constantine the Philosopher University in Nitra

Drazovska 4

Nitra

Slovakia

National Institute for Education

Department special pedagogy and inclusion

Pluhova 8

Bratislava

Slovakia

dominika.hosova@ statpedu.sk 